\title{
Induction Motor Voltage Amplitude Control Technique based on the Motor Efficiency Observation
}

\author{
V. Bleizgys, A. Baskys, T. Lipinskis \\ Center for Physical Sciences and Technology, \\ A. Gostauto 11, LT-01108 Vilnius, Lithuania, phone+370 5 2613989, e-mail: mel@pfi.lt \\ Faculty of Electronics, Vilnius Gediminas Technical University, \\ Naugarduko str.41,LT-03227,Vilnius, Lithuania; phone: +370 5 2744767,e-mail: algirdas.baskys@vgtu.lt
}

\section{Introduction}

The main problem in control of $\mathrm{AC}$ induction motor speed is control of amplitude of AC voltage provided by the frequency converter. There are two widely used amplitude control methods: scalar and vector control [1-7].

The scalar control is based on the steady-state model of motor. The linear law of voltage amplitude control (ratio amplitude to phase frequency $U_{A} / f_{p}=$ const) should be applied to keep the magnetizing flux of the motor practically unchanged according this model. This allows us to keep the torque of the motor nearly independent on the motor velocity. The scalar control is used when the motor load is approximately independent on motor speed or if load dependence on speed is known in advance.

If the motor load changes randomly and the fast response is needed the vector control is used. It is based on the dynamic model of the motor. The instant values of speed and flux of motor should be measured for full realization of vector control. However, it is complicated to provide these measurements [8]. Therefore, if the control of motor is not relevant at very low speed, the sensorless method of vector control can be used $[1,3]$.

The equations of motor dynamic model must be solved and the data for calculations should be extracted from the motor phases current transients in real time for realization of sensorless vector control. Because of this, complex algorithms must be applied and, as consequence, expensive high performance DSP should be employed for vector control realization [6].

In this work we would like to present some alternative for vector control. The proposed method is based on the observation of motor phase current amplitude instant value. The amplitude of voltage is controlled in real time in such a way that for the given instant motor load and speed the instant phase current amplitude would be minimal (the efficiency of the motor would be maximal). The realization of this method of voltage amplitude control is less complicated as compared to vector control. It is enough to measure the motor phase current amplitude and to find in the real time the amplitude of voltage, at which phase current at given instant motor load and speed is minimal. The proposed motor supply voltage amplitude control method is relevant because the efficiency of motor is one of the main characteristics of electric motor drives [9-11].

\section{Investigation of the inverter and motor phase current}

The experimental investigation of the inverter DC current $\left(I_{D C}\right)$ and motor phase current amplitude $\left(I_{P}\right)$ on amplitude of voltage supplied by the frequency converter $\left(U_{A}\right)$ was provided to obtain the initial data for development of $U_{A}$ control technique. The experimental example of the frequency converter developed in Center for Physical Sciences and Technology was used for this purpose. The block diagram of the frequency converter is given in Fig.1. It contains rectifier, which converts standard 3 phase AC voltage to DC voltage, and inverter that converts $\mathrm{DC}$ voltage to variable frequency variable amplitude 3 phase AC voltage for motor supply. The

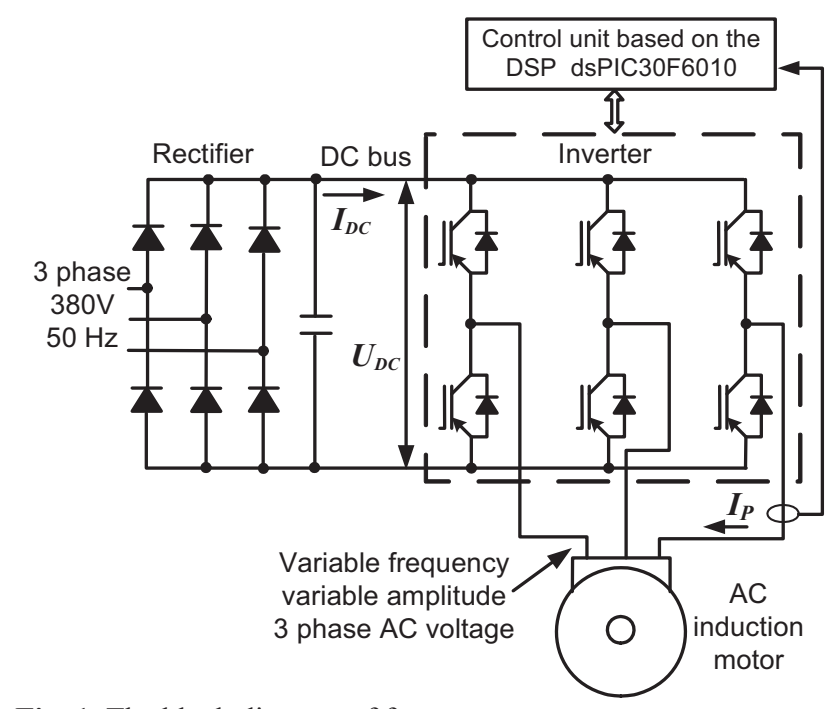

Fig. 1. The block diagram of frequency converter 
control unit controls the operating of the frequency converter and implements the Space Vector Pulse Width Modulation (SVPWM) method [2, 3] for switching of inverter transistors.

The maximal efficiency of the motor supplied by the frequency converter at given motor load and speed corresponds to minimal $I_{D C}$, which is taken from the DC bus by inverter (Fig.1). The experimental dependences of $I_{D C}$ and $I_{P}$ on the $U_{A}$ for various phase frequency $\left(f_{p}\right)$ (for various speed of motor) and motor load torque values are presented in Fig. 2. The results are obtained for $4 \mathrm{~kW}$ (speed 2900rpm at $f_{p}=50 \mathrm{~Hz}$ ) AC induction motor. A special test bench was used for this purpose. It includes the $\mathrm{AC}$ induction motor fed from the frequency converter. The motor drives the $5.5 \mathrm{~kW}$ DC generator, which acts as the motor load. The test bench includes the motor load torque and rotation velocity sensors. The investigation results show that the $I_{D C}$ and $I_{P}$ become minimal practically at the same $U_{A}$ value. Therefore, the minimal value of $I_{P}$ can be used as criterion for the estimation of $U_{A}$, at which the motor efficiency is maximal. This is more convenient for $U_{A}$ control realization because the $I_{P}$ dependence minimum is expressed stronger as compared to $I_{D C}$ minimum (Fig. 2).

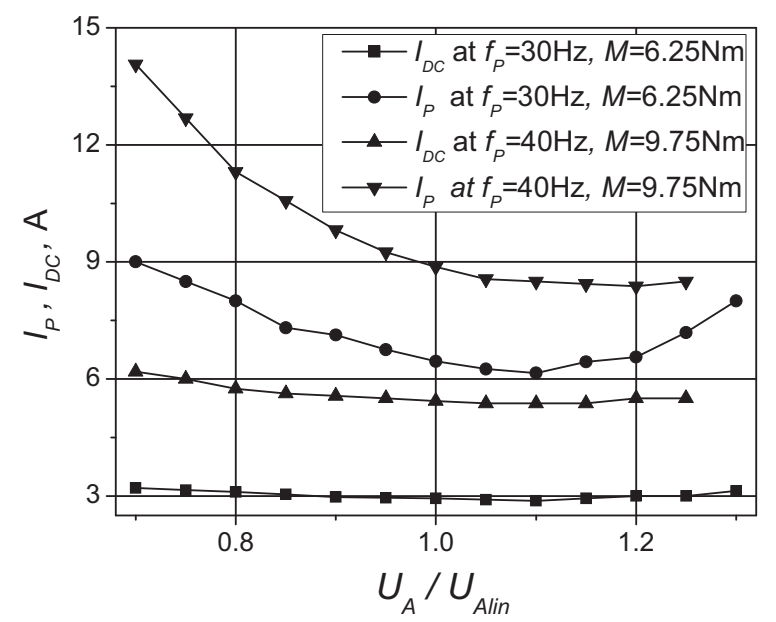

Fig. 2. The dependences of the inverter DC bus current and motor supply phase current amplitude on the relative voltage amplitude at various phase frequency (at various motor speed) and motor load torque. The $U_{A}$ lin is the amplitude of voltage required by the linear voltage amplitude control law

The experimental dependences of $I_{P}$ on the relative value of $U_{A}$ for various motor load torque values at $f_{p}=30 \mathrm{~Hz}$ (at $1700 \mathrm{rpm}$ motor speed) are presented in Fig. 3. It is seen that the $U_{A}$ value, at which $I_{P}$ is minimal and, consequently, motor efficiency is maximal, depends strongly on motor load torque.

The dependences of the relative value of $U_{A}$ on the motor load torque, which correspond to minimal $I_{P}$ (maximal motor efficiency), for various $f_{p}$ (various motor speed) are given in Fig.4. The control algorithm employed in the frequency converter should guarantee the variation of $U_{A}$ in accordance with these dependences.

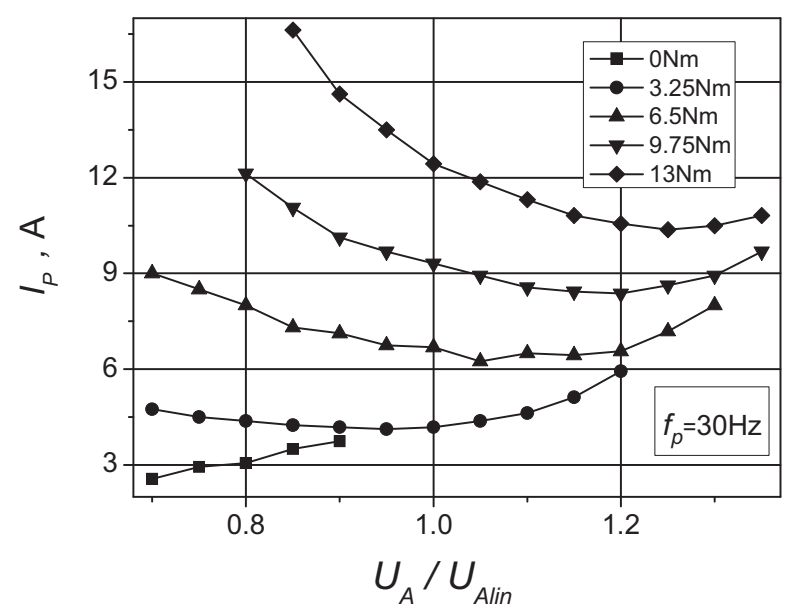

Fig. 3. The dependences of the motor supply phase current amplitude on the relative voltage amplitude at $f_{p}=30 \mathrm{~Hz}$ and various motor load torque values

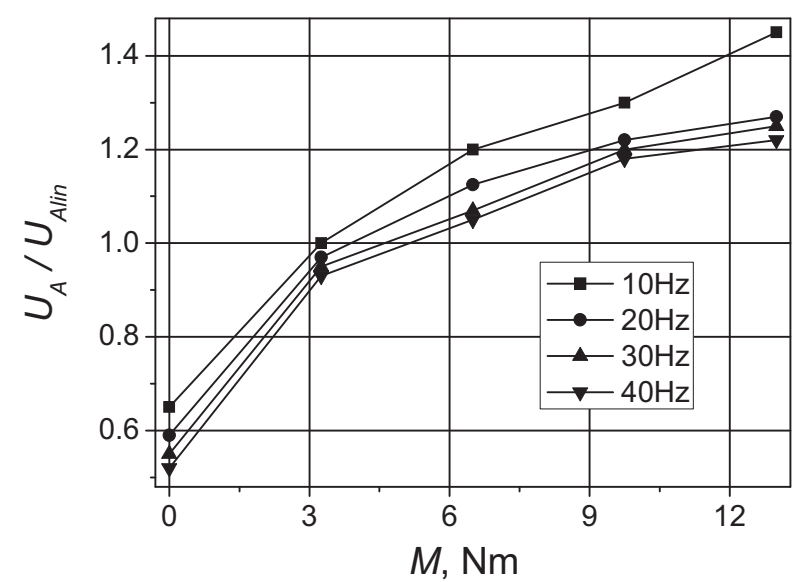

Fig. 4. The dependences of the relative motor supply voltage amplitude, which correspond to minimal motor phase current amplitude, on motor load torque at various phase frequencies

\section{Motor supply voltage amplitude control algorithm}

The purpose of the $U_{A}$ control is to keep the $U_{A}$ value, at which the efficiency of the motor is close to maximal, i.e., at which the $I_{P}$ would be close to minimal. The results obtained during the experimental investigation show that $I_{P}$ depends strongly on motor load and speed and has the only minimum (Figs. 2 and 3). The single variable optimization problem should be solved continuously in the real time. The aim of the optimization is to select the value of $U_{A}=U_{\text {Aopt }}$ from the $Q$ region of possible values, at which

$$
\begin{gathered}
I_{p}\left(U_{\text {Aopt }}\right)=\min I_{p}\left(U_{\mathrm{A}}\right) . \\
U_{\mathrm{A}} \in Q
\end{gathered}
$$

The range of possible values of $U_{A}$ is split up in to the zones with the even width $\Delta U_{A}$ (Fig. 5). There are $n$ zones where $U_{A}<U_{A 0}$ and $m$ zones where $U_{A} \geq U_{A 0}$. 


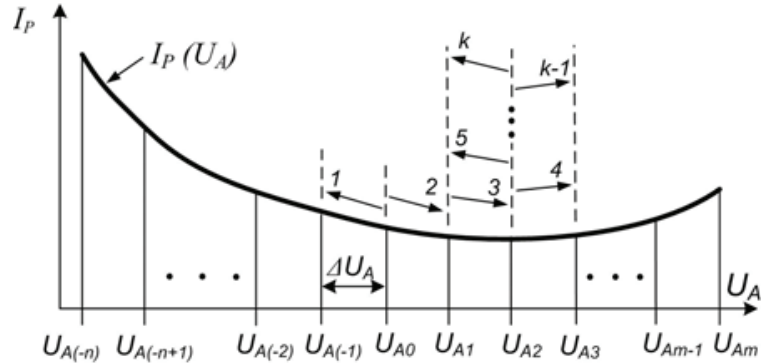

Fig. 5. The algorithm of phase current amplitude minimum search

The developed algorithm of function $I_{P}\left(U_{A}\right)$ minimum search is as follows:
Step 1 set $j=0$,
Step 2 if $I_{P}\left(U_{A j-1}\right) \geq I_{P}\left(U_{A j}\right)$ and $j<m$,
Step 3 increment $j$ by 1 and goto Step 2,
Step 4 else decrement $j$ by 1 ,
Step 5 if $I_{P}\left(U_{A j}\right) \leq I_{P}\left(U_{A j+1}\right)$ and $j>-n$,
Step 6 decrement $j$ by 1 and goto Step 5,
Step 7 else goto Step 3,

where $j=-n,-n+1, \ldots .,-2,-1,0,1,2, \ldots, m-1, m$.

The initial value $U_{A}=U_{A 0}$ for function $I_{P}\left(U_{A}\right)$ minimum search using algorithm (2) corresponds to the value of $U_{A}$ obtained at given $f_{p}$ for linear control law (for law $U_{A} / f_{p}=$ const). The $U_{A}$ in the proposed algorithm has only discrete values with $\Delta U_{A}$ discreteness (Fig 5). First of all, the values of $I_{P}$ at $U_{A}=U_{A 0}$ and $U_{A}=U_{A(-l)}$ are measured and compared according the algorithm (2) (move 1 in Fig. 5), i.e. the gradient of function is tested moving to the left. Since the function increases, the movement direction is changed and values of $I_{P}$ at $U_{A}=U_{A I}$ (move 2 in Fig. 5), $U_{A}=U_{A 2}$ (move 3) and $U_{A}=U_{A 3}$ (move 4) are measured. The increment of function during the 4 th move is registered, therefore, the minimum of function is in range $U_{A I}<U_{A}<U_{A 3}$. The algorithm changes the movement direction (makes move 5) and after that cyclically repeats moves 4 and 5. If the motor operating conditions (load torque, speed) changes and function minimum moves out of range $U_{A I}<U_{A}<U_{A 3}$, the algorithm (2) seeks again the function minimum in the same way.

\section{Implementation and investigation of the motor supply voltage amplitude control algorithm}

The proposed motor supply voltage amplitude control algorithm (2) was employed in the experimental example of the frequency converter, which implements the SVPWM method for the three phase variable frequency and amplitude voltage forming. It was realized using DSP dsPIC30F6010. The isolation amplifier with short circuit and overload detection HCPL788J was employed for measurement of the phase current. The investigation of the developed algorithm was performed using the test bench and $\mathrm{AC}$ induction motor mentioned in this paper previously. The width of zone $\Delta U_{A}=0.03 U_{A 0}$ was chosen for the realization of the algorithm. The discrete change of $U_{A}$ values and measurement of $I_{P}$ was provided every $0.5 \mathrm{~s}$ during the function $I_{P}\left(U_{A}\right)$ minimum search, i.e. the $U_{A}$ change discreetness in time $\Delta t=0.5 \mathrm{~s}$. The measurement of $I_{P}$ was not reliable if $\Delta t<0.5 \mathrm{~s}$. The reason is that the response of the $I_{P}$ measurement circuit output to $I_{P}$ change is slow due to the low-pass filter, which is essential because of the high EMD produced by the inverter.

The response of the $I_{P}$ to motor load torque pulse change for the case when the proposed $U_{A}$ control method is employed is given in Fig.6a. The obtained transients are compared to the transients gained using linear control of $U_{A}$ (Fig.6b). They show that the developed $U_{A}$ control method guarantees lower steady state value of $I_{P}$, i.e. higher motor efficiency as compared to the case when linear control of $U_{A}$ is used. Additionally, it provides lower load torque overshoot and, as a consequence, lower AC induction motor drive overload during the instant load torque increment. On the other hand, it is seen that the $I_{P}$ overshoot is higher and has longer duration in the case when proposed control method is employed (compare transients given in Figs.6a and $6 \mathrm{~b}$ ). Consequently, the proposed $U_{A}$ control method based on the $I_{P}$ observation can be used effectively in the situations when the fast response of the motor supply voltage is not needed.

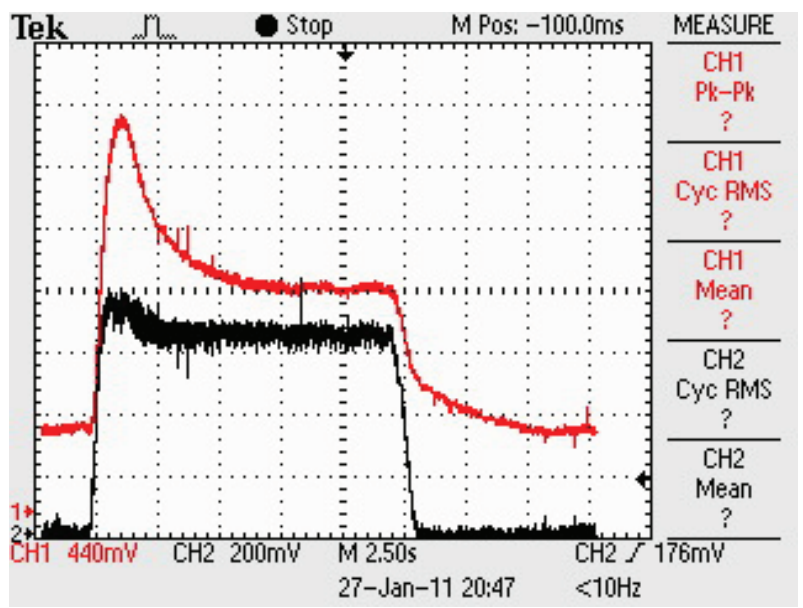

a)

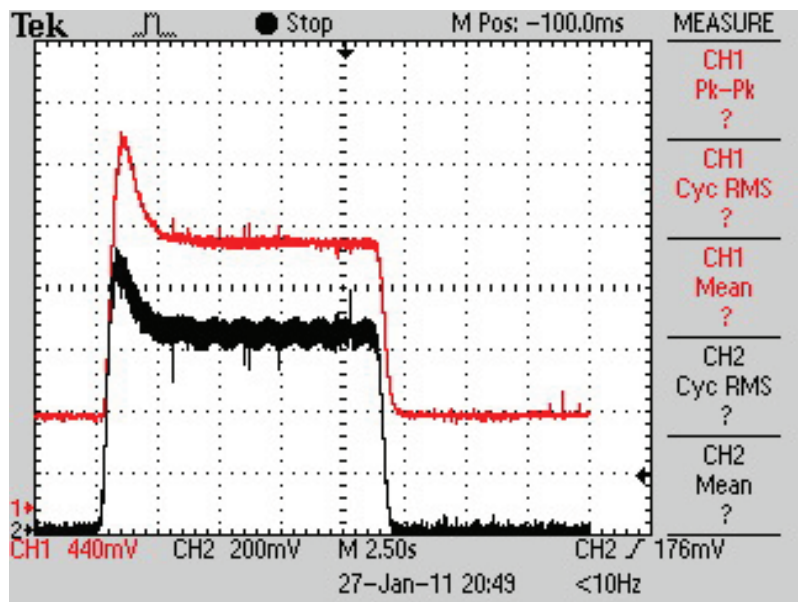

b)

Fig. 6. The response oh the motor phase current amplitude (upper curves, $1 \mathrm{div}=2.5 \mathrm{~A}$ ) to pulse change of motor load torque (bottom curves, 1 div $=4 \mathrm{Nm}$ ) when motor supply voltage amplitude control based on the motor phase current amplitude observation (a) and linear amplitude control (b) are applied. The transients are obtained at $30 \mathrm{~Hz}$ phase frequency 


\section{Conclusions}

The proposed AC induction motor supply voltage amplitude control algorithm, which is some alternative for the vector control, allows us to vary the amplitude automatically in such a way that the efficiency of the motor at given motor load torque and rotation speed would be maximal. The realization of the algorithm is more simple and cheap as compared to the vector control algorithms. However, the developed algorithm can be applied if the fast response of the motor supply voltage amplitude is not needed.

\section{Acknowledgement}

The authors would like to thank Ph.D. student of Vilnius University Mr. Andrius Bleizgys for help in creating of program for data processing.

\section{References}

1. Kazmierkowski M. P., Krishnan P., Blaabjerg F. Control in Power Electronics. Selected Problems. - Elsevier Science, 2002. -627 p.

2. Baskys A., Bleizgys V., Gobis V. The impact of output voltage modulation strategies on power losses in inverter. //Electronics and Electrical Engineering. - Kaunas: Technologija, 2009. - No. 6(94). - P. 47-50.

3. Neacsu D. Space Vector Modulation // Proceedings of the 27th Annual IEEE Industrial Electronics Society Conference. - Denver, 2001. - P. 1583-1592.
4. Rinkevičienė R., Batkauskas $\mathbf{V}$. Influence of the Inverter Boost Voltage on the Transients of Variable Speed Drives //Electronics and Electrical Engineering. - Kaunas: Technologija, 2009. - No. 4(92). - P. 75-78.

5. Valentine R. Motor Control Electronics Handbook. McGraw-Hill, 1998. - 754 p.

6. Mehrizi-Sani A., Filizadeh S., Wilson P. L. Harmonic and Loss Analysis of Space-Vector Modulated Converters // Proceedings of the Int. Conference on Power Systems Transients IPST'07. - Lyon, 2007. - P. 1-6.

7. Petrovas A., Lisauskas S., Batkauskas V., Baskys A. Variable Speed Drive Supplied by the Voltage Formed using Special-purpose Algorithm // Electronics and Electrical Engineering. - Kaunas: Technologija, 2008. - No. 7(87). - P. 53-56.

8. Grouni S., Ibtiouen R., Kidouche M., Touhami O. Real Time Rotor Flux Estimation for Induction Machine Drives: an Experimental Approach // Electronics and Electrical Engineering. - Kaunas: Technologija, 2010. - No. 8(104). P. 69-72.

9. Jankūnas V., Eidukas D., Guseinovienė E., Cirtautas V. Investigation of Supply Posibilities of Mechatronic Actuator $/ /$ Electronics and Electrical Engineering. - Kaunas: Technologija, 2009. - No. 5(93). - P. 25-28.

10. Bleizgys V., Baskys A. The Influence of Supply Voltage Amplitude Variation Law on AC Induction Motor Efficiency in Variable-Speed Drive // Solid state phenomena, 2010. Vol.164. -P. 1-4.

11. Aghion C., Ursaru O., Lucanu M. Three-Phase Motor Control using Modified Reference Wave // Electronics and Electrical Engineering. - Kaunas: Technologija, 2010. - No. 3(99). - P. 35-38.

V. Bleizgys, A. Baskys, T. Lipinskis. Induction Motor Voltage Amplitude Control Technique based on the Motor Efficiency Observation // Electronics and Electrical Engineering. - Kaunas: Technologija, 2011. - No. 3(109). - P. 89-92.

The technique of voltage amplitude control of AC induction motor supplied by the frequency converter has been proposed. It is based on the observation of motor phase current amplitude value. The amplitude of motor supply voltage is controlled in real time in such a way that for given instant motor load and speed the phase current amplitude would be minimal, i.e. the efficiency of the motor would be maximal. The realization of this method of voltage amplitude control is less complicated as compared to vector control. It is enough to provide the continuous measurement of motor phase current amplitude and to find in the real time the amplitude of voltage, at which phase current amplitude is minimal. The proposed technique can be applied in the situations when the fast response of the motor supply voltage amplitude is not needed. The developed technique has been investigated experimentally using special test bench. Ill. 6 , bibl. 11 (in English; abstracts in English and Lithuanian).

V. Bleizgys, A. Baškys, T. Lipinskis. Asinchroninio elektros variklio ịtampos amplitudès valdymo metodas, pagrịstas variklio naudingumo veiksnio stebėjimu // Elektronika ir elektrotechnika. - Kaunas: Technologija, 2011. - Nr. 3(109). - P. 89-92.

Pateikiamas asinchroninio elektros variklio, maitinamo dažnio keitiklio, itampos amplitudès valdymo metodas. Jis remiasi variklio srovès amplitudès stebejjimu. Variklio maitinimo įtampos amplidudè valdoma realiu laiku, taip, kad, esant tam tikrai variklio apkrovai ir greičiui, srovès amplitudè būtų minimali, t. y. variklio naudingumo veiksnys būtų maksimalus. Toks variklio ịtampos amplitudès valdymas yra paprastesnis nei vektorinis valdymas. Tam pakanka nepertraukiamai matuoti variklio srovès amplitudę ir realiu laiku nustatyti, kokia turètų būti ịtampos amplitudè, kad, esant tam tikriems variklio apkrovai ir greičiui, srovès amplitudè būtų minimali. Metodas taikytinas, kai nebūtina, kad variklio maitinimo įtampos amplitudè sparčiai keistųi. Sukurtas metodas ištirtas eksperimentiškai, naudojant specialų tyrimo stendą. Il. 6, bibl. 11 (anglų kalba; santraukos anglų ir lietuvių k.). 